\title{
Sialic acid residue of ovine angiotensinogen does not affect the reactivity to human renin
}

\author{
Akio Ebihara ${ }^{1}$, Uddin Mohammad Nasir ${ }^{2}$, Shigeki Yoshida ${ }^{1}$, Takao Kondou ${ }^{3}$, Tsutomu Nakagawa ${ }^{3}$, \\ Akiyoshi Fukamizu' ${ }^{1,4}$, Fumiaki Suzuki ${ }^{5}$, Yukio Nakamura ${ }^{3}$ and Kazuo Murakami ${ }^{1}$ \\ ${ }^{1}$ Institute of Applied Biochemistry, University of Tsukuba, Tsukuba, Ibaraki 305-8572, ${ }^{2}$ United Graduate School of Agricultural \\ Science and ${ }^{3}$ Department of Biotechnology, Faculty of Agriculture, Gifu University, Gifu 501-1193, ${ }^{4}$ Center for Tsukuba \\ Advanced Research Alliance, University of Tsukuba, Tsukuba, Ibaraki 305-8577, ${ }^{5}$ Molecular Genetics Research Center, Gifu \\ University, Gifu 501-1193, Japan
}

(Received 7 March 2000; and accepted 25 April 2000)

\begin{abstract}
Recombinant ovine angiotensinogen (oANG) expressed in Chinese hamster ovary cells was purified into five isoforms by ammonium sulfate precipitation, CM-Toyopearl column chromatography and chromatofocusing. These isoforms (A-1, A-2, A-3, A-4 and A-5) had apparent molecular weight of 52,000 and isoelectric points of 6.5, 6.3,6.3, 6.0 and 5.7, respectively. Each of the isoforms ran in a single band on sodium dodecyl sulfatepolyacrylamide gel electrophoresis and isoelectric focusing. After desialylation by neuraminidase, oANG gave one major band with isoelectric point of 6.9. The isoforms, A-2, A-3 and A-4 had similar $K_{\mathrm{m}}$ and $V_{\max }$ values to human renin $\left(95 \%\right.$ confidence limit: $K_{\mathrm{m}}=$ $0.17+/-0.07,0.15+/-0.04$ and $0.18+/-0.01 \mu \mathrm{M} ; V_{\max }=0.90+/-0.17,0.81+/-0.07$ and $0.88+/-0.03 \mathrm{nM} / \mathrm{min}$, respectively). These values for desialylated and untreated oANGs were also similar $\left(95 \%\right.$ confidence limit: $K_{\mathrm{m}}=0.11+/-0.03$ and $0.15+/-0.03 \mu \mathrm{M} ; V_{\max }=$ $0.72+/-0.06$ and $0.79+/-0.06 \mathrm{nM} / \mathrm{min}$, respectively). These results indicate that sialic acid residue of recombinant $\mathrm{OANG}$ does not affect the reactivity to human renin.
\end{abstract}

Angiotensinogen is a plasma glycoprotein and is specifically cleaved by renin (EC 3.4.23.15) to release the $\mathrm{N}$-terminal decapeptide, angiotensin I (AI). AI is subsequently cleaved by angiotensinconverting enzyme (EC 3.4.15.1) to produce the octapeptide, angiotensin II, which regulates blood pressure and electrolyte balance (7).

Many investigators reported that angiotensinogen purified from plasma displays several isoforms different in the molecular weight and isoelectric point (pI), and that the heterogeneity is mainly due to the difference in carbohydrate content $(4,7,8,18)$. In particular, the difference

Correspondence to: Dr Yukio Nakamura at the above address. Fax: + 81-58-293-2907; E-mail:n-yukio @cc.gifu-u.ac.jp in sialic acid content causes the charge heterogeneity of angiotensinogen $(4,8,18)$. On the other hand, sialic acid residue of glycoprotein is assumed to affect interaction between proteins $(5$, 9, 12, 17, 20). For example, Imai et al. showed that desialylated erythropoietin exhibits a 4-fold higher binding affinity to its receptor than that untreated, which indicates that sialic acid residue of erythropoietin decreases the affinity to the receptor (9). These findings raise the possibility that angiotensinogen with sialic acid residue exhibits a difference in the affinity and/or catalytic activity to renin.

In this study, we used recombinant ovine angiotensinogen (oANG) expressed in Chinese hamster ovary (CHO) cells to examine whether sialic acid residue of angiotensinogen affects the 
affinity and catalytic activity to renin.

Purification of recombinant oANG using chromatofocusing. Recombinant oANG expressed in CHO cells was purified 1.7 -fold by $70 \%$ saturated ammonium sulfate precipitation $(\mathrm{pH} 7)$ and was eluted in a single peak by $\mathrm{CM}$-Toyopearl column chromatography (15). The oANGcontaining fraction (fraction A) was chromatofocused to be separated into five isoforms (A-1, A-2, A-3, A-4 and A-5) with elution $\mathrm{pH}$ values of $6.6,6.4,6.3,6.1$ and 5.8 , respectively

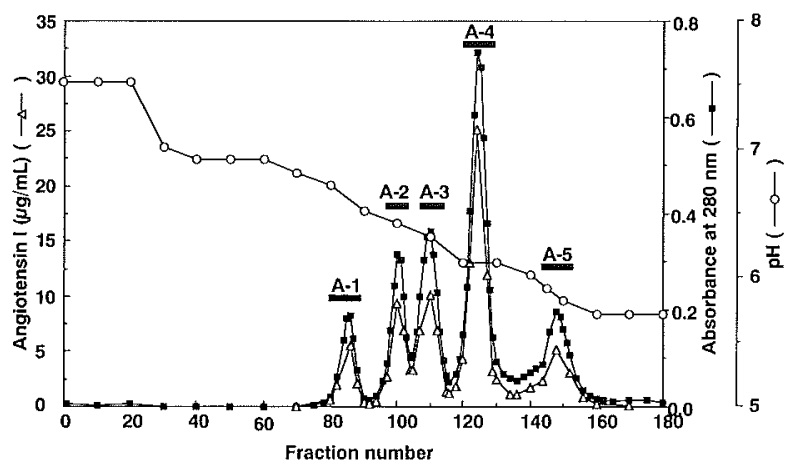

Fig. 1 Chromatofocusing of oANG on a polybuffer exchanger 94 column. oANG preparation obtained by CM-Toyopearl column chromatography was dialysed against $25 \mathrm{mM}$ imidazole- $\mathrm{HCl}$ buffer, $\mathrm{pH}$ 7.4. The dialysate was diluted into 0.06 of absorbance at $280 \mathrm{~nm}$, incubated for $6 \mathrm{~h}$ and applied to a column $(1.0 \times 23 \mathrm{~cm})$ of Polybuffer exchanger 94 (Pharmacia Biotech AB, Uppsala, Sweden) preequilibrated with the imidazole buffer. The preparation was eluted by a $\mathrm{pH}$ gradient generated with Polybuffer $74-\mathrm{HCl}, \mathrm{pH} 5.0$ (dilution factor, $\mathrm{I}: 8$ ) at a flow rate of $0.17 \mathrm{~mL} / \mathrm{min}$.
(Fig. 1). All isoforms ran in a single band with molecular weight of 52,000 on sodium dodecyl sulfate-polyacrylamide gel electrophoresis (SDSPAGE; 11). Also the isoforms ran in a single band on isoelectric focusing (IEF) with pI values of $6.5,6.3,6.3,6.0$ and 5.7, respectively (data not shown). The resolution of chromatofocusing shown here is similar to that of plasma oANG previously reported by Fernley et al. (4). The $\mathrm{N}$-terminal amino acid sequence of all the isoforms was determined to be Asp-Arg-Val-Tyr-Ile, which is identical to that of $\mathrm{AI}$, using a protein sequencer (Procise 491, Perkin-Elmer Co., Applied Biosystems Div., Foster City, CA). Purification of recombinant $O A N G$ is summarised in Table 1. The concentration of AI was measured using AI-enzyme-linked immunosorbent assay $($ AI-ELISA) $(15,19)$ and total protein concentration was measured as described by Bradford (2). The isoforms were purified about 3-fold with an overall yield of $31 \%$ by these procedures. The specific activity of the isoforms avaraged $22.4 \mu \mathrm{g}$ $\mathrm{AI} / \mathrm{mg}$ protein and the purity is estimated to be $91 \%$, because the theoretical specific activity of pure oANG is calculated to be $24.6 \mu \mathrm{g} \mathrm{AI} / \mathrm{mg}$ assuming that molecular weights of $\mathrm{AI}$ and oANG are 1,300 and 52,000, respectively.

Charge heterogeneity of recombinant $O A N G$. Recombinant oANG displayed the charge heterogeneity on IEF, although the molecular weight of all isoforms was 52,000 . The molecular weight is higher by 3,000 than that calculated from the amino acid sequence (14), agreeing with the previous data reported by Inui et al. (10). The increase of molecular weight is probably due to oligosaccharides attached to the two potential

Table 1 Purification of recombinant ovine angiotensinogen

\begin{tabular}{|c|c|c|c|c|c|c|}
\hline Purification step & $\begin{array}{l}\text { Volume } \\
(\mathrm{mL})\end{array}$ & $\begin{array}{l}\text { Total AI } \\
(\mu \mathrm{g})\end{array}$ & $\begin{array}{l}\text { Total protein } \\
\text { (mg) }\end{array}$ & $\begin{array}{c}\text { Specific } \\
\text { activity } \\
(\mu \mathrm{g} \mathrm{AI} / \mathrm{mg})\end{array}$ & $\begin{array}{l}\text { Purification } \\
\text { (fold) }\end{array}$ & $\begin{array}{c}\text { Recovery } \\
\text { (\%) }\end{array}$ \\
\hline Conditioned medium & 2880 & 844 & 108 & 7.84 & 1.0 & 100 \\
\hline Ammonium sulfate precipitation & 54 & 578 & 44.3 & 13.0 & 1.7 & 65 \\
\hline CM-Toyopearl column chromatography & 69 & 337 & 16.4 & 20.5 & 2.6 & 40 \\
\hline \multicolumn{7}{|l|}{ Chromatofocusing } \\
\hline A-1 & 5.1 & 19.0 & 0.928 & 20.5 & 2.6 & 2.3 \\
\hline$A-2$ & 5.1 & 37.8 & 1.68 & 22.5 & 2.9 & 4.5 \\
\hline$A-3$ & 6.0 & 53.9 & 2.20 & 24.5 & 3.1 & 6.4 \\
\hline$A-4$ & 6.8 & 127 & 5.25 & 24.2 & 3.1 & 15 \\
\hline$A-5$ & 6.8 & 27.3 & 1.36 & 20.1 & 2.6 & 3.2 \\
\hline
\end{tabular}


$N$-linked glycosylation sites $(10,14)$. Moreover, $60 \%$ of $\mathrm{N}$-linked oligosaccharides of glycoprotein expressed in $\mathrm{CHO}$ cells contain sialic acid residues (1). Therefore, sialic acid residue should be a main factor to make the charge heterogeneity of recombinant oANG.

Desialylation of recombinant oANG. oANG $(0.5 \mathrm{mg})$, obtained by CM-Toyopearl column chromatography, was incubated at $37^{\circ} \mathrm{C}$ for $24 \mathrm{~h}$ with $50 \mathrm{mU}$ of neuraminidase from Vibrio cholerae (EC 3.2.1.18, Boehringer Mannheim $\mathrm{GmbH}$, Germany) in $100 \mu \mathrm{L}$ of $50 \mathrm{mM}$ sodium acetate buffer, pH 5.5 containing $77 \mathrm{mM} \mathrm{NaCl}$ and 6.5 $\mathrm{mM} \mathrm{CaCl}$. The progress of desialylation was

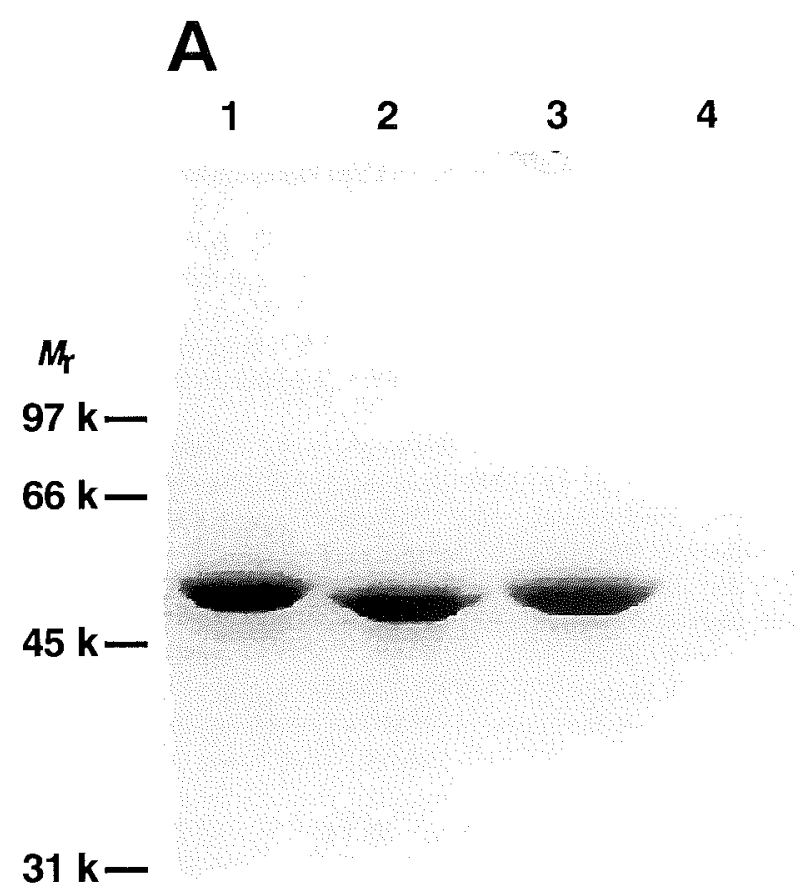

monitored by native PAGE (3). After desialylation by neuraminidase, oANG gave one major band at pI 6.9 with two minor bands on IEF, whereas untreated oANG gave five bands in the pI range of 5.7 to 6.6 (Fig. 2B, lanes 1 and 2). The increase of $\mathrm{pI}$ value to 6.9 is consistent with the release of sialic acid residues. In contrast, incubation of oANG without neuraminidase caused a small shift in pI toward alkaline side (Fig. 2B, lane 3) but fragmentation of the preparation did not occur (Fig. 2A, lane 3), which indicates that a slight amount of sialic acid residue is removed during the incubation without the enzyme. These results indicate that sialic acid residue is a main

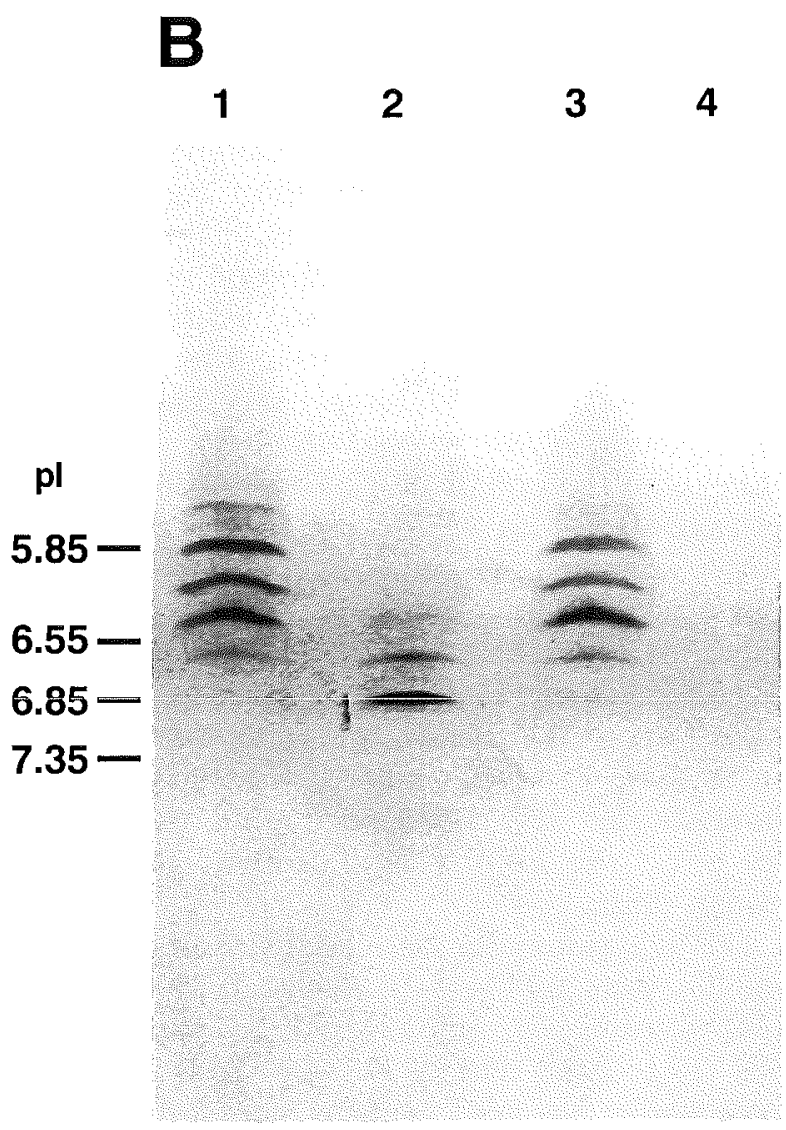

Fig. 2 SDS-PAGE and IEF of desialylated oANG. Panel $A$, SDS-PAGE. Lane 1, untreated oANG $(2 \mu \mathrm{g})$; lane 2, oANG incubated with neuraminidase $(2 \mu \mathrm{g})$; lane 3 , oANG incubated without neuraminidase $(2 \mu \mathrm{g})$; lane 4, neuraminidase (no oANG). Molecular weight $\left(M_{\mathrm{r}}\right)$ of marker protein was shown to the left. Proteins were stained by Coomassie Brilliant Blue R-250 (CBB R-250). Panel B, IEF. A flat bed gel containing 6\% (w/ v) acrylamide and 2\% (w/v) ampholytes (Pharmalyte 3-10, Pharmacia Biotech AB, Uppsala, Sweden) was used to develope a $\mathrm{pH}$ gradient of 3.0 to 10 . Proteins separated by IEF were transferred to a polyvinylidene difluoride membrane after a 30 min immersion of the gel in the transfer buffer containing $0.1 \%(\mathrm{w} / \mathrm{v})$ SDS. Transferred proteins were stained by CBB R-250. Lane 1, untreated oANG $(5 \mu \mathrm{g})$; lane 2, oANG incubated with neuraminidase $(5 \mu \mathrm{g})$; lane 3 , oANG incubated without neuraminidase $(5 \mu \mathrm{g})$; lane 4 , neuraminidase (no oANG). The pI value of marker protein was shown to the left. 
factor to cause the charge heterogeneity of recombinant oANG. The remaining charge heterogeneity of desialylated oANG (Fig. 2B, lane 2) is probably attributed to other posttranslational modifications such as phosphorylation, sulfation (6), sialylation of $O$-linked oligosaccharide (5) or truncation of C-terminal amino acid (21).

Kinetic parameters of intact and desialylated recombinant oANGs. Various concentrations $(0.0-0.5 \mu \mathrm{M})$ of oANG were incubated with recombinant human renin at $37^{\circ} \mathrm{C}$ for $30 \mathrm{~min}$ in $74 \mathrm{mM}$ sodium phosphate buffer, $\mathrm{pH} 6.5$ containing $7.4 \mathrm{mM}$ diisopropyl fluorophosphate and 7.4 $m M$ EDTA $(13,16)$. The recombinant human renin used in this study was produced as prorenin in $\mathrm{CHO}$ cells and activated by trypsin (16). The rate of AI production was determined by AIELISA. The Michaelis constant $\left(K_{\mathrm{m}}\right)$ and maximum velocity $\left(V_{\max }\right)$ were estimated with the software, UltraFit (Biosoft, Cambridge, UK) using Michaelis-Menten equation as a fitting equation and were expressed as $95 \%$ confidence limits. The $K_{\mathrm{m}}$ values for reaction of human renin with fractions A-2, A-3, A-4 and fraction A were $0.17+/-0.07,0.15+/-0.04,0.18+/-0.01$ and $0.17+/-0.05 \mu \mathrm{M}$, respectively, and the $V_{\max }$ values were $0.90+/-0.17,0.81+/-0.07$, $0.88+/-0.03$ and $0.77+/-0.08 \mathrm{nM} / \mathrm{min}$, respectively. These kinetic parameters are almost similar among fractions A-2, A-3, A-4 and fraction $A$. On the other hand, all these fractions were sialylated and probably have the different content of sialic acid, because a single sialic acid residue causes the difference in pI value of angiotensinogen $(4,8)$. The result of kinetic parameter indicates that sialic acid residue of oANG does not affect the affinity and catalytic activity to human renin.

The $K_{\mathrm{m}}$ values for desialylated and untreated oANGs were $0.11+/-0.03$ and $0.15+/-0.03$ $\mu \mathrm{M}$, respectively, and the $V_{\max }$ values were $0.72+/-0.06$ and $0.79+/-0.06 \mathrm{nM} / \mathrm{min}$, respectively. No marked differences are observed in the kinetic parameters between desialylated and untreated oANGs, which indicates that the removal of sialic acid residue from oANG does not change the affinity and catalytic activity to human renin. These two results of kinetic parameter suggest that sialic acid residue of angiotensinogen does not affect the reactivity to renin.

\section{REFERENCES}

1. Aeed P. A., Guido D. M., Mathews W. R. and Elhammer A. P. (1992) Characterization of the oligosaccharide structures on recombinant human prorenin expressed in Chinese hamster ovary cells. Biochemistry 31, 6951 6961.

2. Bradford M. M. (1976) A rapid and sensitive method for the quantitation of microgram quantities of protein utilizing the principle of protein-dye binding. Anal. Biochem. $72,248-254$.

3. Davis B. J. (1964) Disc electrophoresis-II. Method and application to human serum proteins. Ann. N. Y. Acad. Sci. 121, 404-427.

4. Fernley R. T., John M., Niall H. D., and Coghlan J. P. (1986) Purification and characterization of ovine angiotensinogen. Eur. J. Biochem. 154, 597-601.

5. Goochee C. F., Gramer M. J., Andersen D. C., Bahr J. B. and Rasmussen J. R. (1991) The oligosaccharides of glycoproteins: Bioprocess factors affecting oligosaccharide structure and their effect on glycoprotein properties. Bio/ Technology 9, 1347-1355.

6. Gray D. (1997) Overview of protein expression by mammalian cells. In: Current Protocols in Protein Science (Coligan J. E., Dunn B. M., Ploegh H. L., Speicher D. W. and Wingfield P. T., eds.) John Wiley \& Sons, Inc., New York, pp 5.9.1-5.9.18.

7. Griendling K. K., Murphy T. J. and Alexander R. W. (1993) Molecular biology of the renin-angiotensin system. Circulation 87, 1816-1828.

8. Hilgenfeldt U. and Schott R. (1987) Heterogeneity in the carbohydrate structure of rat angiotensinogen. Mol. Cell. Endocrinol. 51, 211-218.

9. Imai N., Higuchi M., Kawamura A., Tomonoh K., OhEda M., Fujiwara M., Shimonaka Y, and Ochi N. (1990) Physicochemical and biological characterization of asialoerythropoietin. Suppressive effects of sialic acid in the expression of biological activity of human erythropoietin in vitro. Eur. J. Biochem. 194, 457-462.

10. Inui Y., Orihashi T., Nakagawa T., Ebihara A., Suzuki F. and Nakamura Y. (1998) Effects of glycosylation of the residue at position 14 in ovine angiotensinogen on the human renin reaction. Biosci. Biotechnol. Biochem. 62, $1612-1614$.

11. Laemmli U. K. (1970) Cleavage of structural proteins during the assembly of the head of bacteriophage T4. Nature 227, 680-685.

12. Lascols O., Cherqui G., Munier A., Picard J and Capeau J. (1994) Differences in both glycosylation and binding properties between rat and mouse liver prolactin receptors. Cell. Mol. Biol. 40, 359-371.

13. Murakami K., Suzuki F., Morita N., Ito H., Okamoto K., Hirose S. and Inagami T. (1980) High molecular weight renin in stroke-prone spontaneously hypertensive rats. Biochim. Biophys. Acta 622, 115-122.

14. Nagase M., Suzuki F., Fukamizu A., Takeda N., Takeuchi K., Murakami K. and Nakamura Y. (1994) Sequencing and expression of sheep angiotensinogen cDNA. Biosci. Biotech. Biochem. 58, 1884-1885.

15. Nagase M., Suzuki F., Sawai Y., Orihashi T., Inui Y., Nakagawa T. and Nakamura Y. (1997) Purification and some properties of recombinant sheep angiotensinogen expressed in Chinese hamster ovary cells. Biomed. Res. 18, 439-443.

16. Nasir U. M., Takahashi K., Nagai T., Nakagawa T., 
Suzuki F. and Nakamura Y. (1998) Two peaks in $\mathrm{pH}$ dependence of renin-angiotensinogen reaction. Biosci. Biotechnol. Biochem. 62, 338-340.

17. Rens-Domiano S. and Reisine T. (1991) Structural analysis and functional role of the carbohydrate component of somatostatin receptors. J. Biol. Chem. 266, 20094-20102.

18. Skeggs L. T., JR., Lentz K. E., Hochstrasser H. and Kahn J. R. (1963) The purification and partial characterization of several forms of hog renin substrate. J. Exp. Med. 118, 73-98.

19. Suzuki F., Yamashita S., Takahashi A., Ito M., Miyazaki
S., Nagata Y. and Nakamura Y. (1990) Highly sensitive microplate-ELISA for angiotensin I using 3, 3', 5, 5' tetramethylbenzidine. Clin. and Exper. Hyper. A12, 8395.

20. Tsuda E., Kawanishi G., Ueda M., Masuda S. and Sasaki R. (1990) The role of carbohydrate in recombinant human erythropoietin. Eur. J. Biochem. 188, 405-411.

21. Walther-Rasmussen J., Johnsen A. H. and Hoiby $N$. (1999) Terminal truncations in Amp $C \beta$-lactamase from a clinical isolate of Pseudomonas aeruginosa. Eur. J. Biochen. 263, 478-485. 